\title{
The Role of Non-Chemical Stressors in Mediating Socioeconomic Susceptibility to Environmental Chemicals
}

\author{
Jane E. Clougherty • Jessie L. C. Shmool • \\ Laura D. Kubzansky
}

Published online: 10 October 2014

(C) Springer International Publishing AG 2014

\begin{abstract}
Growing evidence suggests that lower socioeconomic position (SEP) communities may be more susceptible to environmental exposures. SEP, however, represents a complex mix of social and environmental exposures accumulating over the lifecourse, and those components that most impact susceptibility remain undetermined. One plausible hypothesis is that the chronic psychological stress associated with stressors in many lower-SEP communities (e.g., housing instability, food insecurity, fear of violence) may lead to altered immune, endocrine, and metabolic function. These alterations, together with environmental exposures, may ultimately contribute to increased risk of developing a variety of chronic diseases.

Clearer insight into which specific components of SEP may magnify susceptibility to toxic environmental exposures is needed to improve epidemiologic analyses, and to design more effective environmental health policies and interventions. Here, we compile recent evidence published since 2009 , when we conducted a similar review of this topic, towards developing a better understanding of chronic stress as a possible mediator of SEP-related pollution susceptibility. We discuss recent findings on common patterning (i.e., spatial correlation) between these exposures and methodological needs to facilitate disentangling health effects of nonchemical and chemical stressors. Finally, we briefly discuss the implications of disentangling SEP- and stress-related susceptibility for cumulative risk assessment.
\end{abstract}

J. E. Clougherty $(\bowtie) \cdot$ J. L. C. Shmool

Department of Environmental and Occupational Health, University of Pittsburgh Graduate School of Public Health, Pittsburgh, PA, USA e-mail: jcloughe@pitt.edu

L. D. Kubzansky

Department of Social and Behavioral Sciences, Harvard School of Public Health, Boston, MA, USA
Keywords Socioeconomic status $\cdot$ Stress $\cdot$ Susceptibility . Spatial confounding $\cdot$ Effect modification

\section{Introduction}

Growing evidence indicates that lower-income communities and communities of color may be more susceptible to environmental exposures, including air pollution [1], industrial emissions [2], agricultural hazards [3], and lead $(\mathrm{Pb})$ [4]. Such studies frequently characterize these communities according to socioeconomic position (SEP), which represents a complex mix of social and environmental exposures accumulating over the lifecourse. Although a rich literature examines the utility of various SEP indicators (e.g., income, education) in predicting health outcomes [5], fewer studies aim to identify those specific "causal components" of SEP that lead to poor health or heightened susceptibility to physical environmental agents [6-8]. Accordingly, there have been recent calls for directed research to identify which aspects of SEP most contribute to poor health outcomes [8].

Epidemiologic and toxicologic evidence suggests that chronic psychological stress may modify susceptibility to pollution, and growing evidence documents greater stressor exposures, and more frequent stress response, among lowerSEP populations $[9,10]$. Thus, the chronic stressors associated with low SEP — which may include exposure to housing instability, food insecurity, fear of violence, and other challenges - may be an important component of why lower-SEP individuals seem to be more vulnerable to environmental exposures. Nonetheless, relatively few studies of SEPrelated susceptibility to environmental exposures have examined the potential role of chronic stress as a key component.

Clearer insight into which specific components of SEP may magnify physiologic susceptibility to pollution is needed to produce more informed epidemiological analyses and to 
design more effective interventions. Here, we consider that portion of SEP-related pollution susceptibility that is due to effects of chronic stress, versus other material aspects of SEP such as material deprivation or poor housing. We do so by systematically reviewing recent evidence (since our last review in 2009 [11]) on the interplay between SEP- and chronic stress-related susceptibility to pollution in relation to health, to determine first what is currently known, and then to identify critical gaps in our understanding. Because this area of research is relatively new, we concentrate on the two chemical exposures examined by the majority of the studies in our previous review - outdoor air pollution and $\mathrm{Pb}$ - enabling comparisons of methods and results across studies focused on similar exposures. We include recent findings on common patterning (i.e., spatial correlation) between social stressors and chemical exposures, and discuss methodological needs to facilitate disentangling health effects of non-chemical and chemical stressors. Finally, we briefly discuss the implications of disentangling SEP- and stress-related susceptibility for cumulative risk assessment (CRA).

\section{Background: Chronic Stress and Stress Measurement}

Chronic stress is characterized by recurrent acute stress, or the inability to ameliorate acute stress responses [12]. Hans Selye (1946) [13] first identified a stress-related biological response and characterized it as "non-specific susceptibility". It is now known that chronic stress and associated negative emotional states (e.g., anxiety, anger) can initiate a cascade of immune and neuroendocrine processes, normally starting with activation of the hypothalamic-pituitary-adrenal axis and sympathetic nervous system, which then lead to alterations in endothelial function, production of proinflammatory cytokines, and altered autonomic function. A substantial body of literature is currently available exploring the multiple physiologic mechanisms through which chronic stress leads to alterations in immune, endocrine, and metabolic function [12, 14-17].

The term 'stress' can refer to a number of interdependent aspects of the stress experience, as elucidated under stress process theory [18]. A stressor is the event or condition posing a threat or challenge. Stress appraisal refers to how one evaluates or appraises the stressor. Stress is the perception that demands exceed one's resources and capacity to cope with those demands [19]. Stress response refers to the psychological, behavioral, and/or physiological sequelae which follow a negatively-appraised stressor. These aspects of stress experience are interdependent; a stressor appraised as nonthreatening generally produces no stress response. The best stress assessments measure all facets of this process; however, this is rarely feasible, and instead most studies measure exposure to a strong chronic stressor, typically one unlikely to be positively appraised (e.g., violence). Some studies have used measures focusing on later stages of the stress process, including negative emotional responses (e.g., anxiety, depression) [20-22] or biomarkers of cumulative physiologic wear and tear $[12,23]$.

There is great interest in identifying biomarkers of chronic stress. To date, however, there is no agreed-upon biomarker that can reliably indicate whether an individual is experiencing chronic stress. In the absence of a gold-standard measure, studies have variously used single-item indicators of inflammatory effects [e.g., C-reactive protein (CRP)], diurnal cortisol rhythms, measures of autonomic function (e.g., blood pressure or heart rate variability), or composite measures of dysregulation across multiple systems designed to indicate cumulative physiologic wear and tear (e.g., allostatic load) [12]. A challenge for all of these measures is that, when considering possible synergistic effects of both stress and chemical exposures, the hypothesized pathways (and hence the relevant biologic measures) may be impacted by both types of exposures - possibly limiting the ability of stress biomarkers to disentangle the impacts of these very different exposures. A second issue is that many of the biomarkers or biomarker composites that are used as direct measures of stress are in fact comprised of pre-clinical risk factors for disease. As a result, they may be capturing downstream effects of perceived stress, rather that solely reflecting its occurrence per se. Thus, it remains a topic of some debate as to whether allostatic load, often measured using a composite of cardiometabolic risk factors including CRP, high-density lipoprotein cholesterol, serum triglycerides, and waist-hip circumference $[12,23]$, is indeed an appropriate proxy measure of chronic stress, or rather downstream effects. Given this uncertainty, findings in studies that use allostatic load as a marker of stress per se should be interpreted with some caution.

\section{Methods}

We performed a comprehensive literature search in January 2014 for studies from the past 5 years (published since 2009) in PubMed. Search criteria required any of the terms "socioeconomic status", "socioeconomic position", "psychological stress" or "chronic stress", AND any of "fine particles", "PM", "nitrogen dioxide", " $\mathrm{NO}_{2}$ ", or "Pb". We included air pollutants and $\mathrm{Pb}$ in the search terms because virtually all of the relevant research identified in our 2009 review was on these topics. Given substantial international differences in healthcare access, urban structure, and other stressors related to SEP, we limited epidemiological results to those including US data.

Two researchers performed these searches independently, and all resultant papers that reported new empirical results and specifically tested for interactions (not just mutual adjustment) between chronic stress and pollution were selected for review 
and are presented here, organized as follows: epidemiologic evidence for effect modification by SEP, and by chronic stress; toxicologic evidence for effect modification by chronic stress; and assessment of co-occurrence between SEP or stressors and pollution exposures.

In our previous review, the majority of the studies we found examined air pollutant or chronic $\mathrm{Pb}$ exposures. Thus, we focus this review on those two exemplar exposures, though the range of chemical exposures to which this model of stressrelated susceptibility may apply is undetermined, and may include non-environmental exposures, including the common cold virus [26] or psychotropic drugs [27]. Finally, we focus here on results related to physical health outcomes, including respiratory and cardiovascular disease, and mortality, but note hypothesized synergistic effects on behavioral, mental health, and cognitive outcomes [24].

\section{Results}

Epidemiologic Evidence for Effect Modification by Socioeconomic Position (SEP)

Since 2009, a somewhat richer literature has examined synergistic effects of pollution and SEP, though we found more epidemiologic studies testing SEP interactions for air pollution $(n=6)$ than for $\mathrm{Pb}(n=1)$. One recent review, aimed at identifying the range of evidence-supported modifiers of particulate matter (PM)-related health effects, found mixed evidence of effect modification by SEP [29]. A subsequent metaanalysis-limited to short-term PM exposure effects on hospitalizations and mortality, and examining only four a priori hypothesized modifiers (SEP, age, race, and sex)-likewise reported mixed results for SEP [30॰]. The authors found suggestive evidence of heightened PM susceptibility in lower-SEP strata (variously defined as low community-level mean education or income, higher poverty rates, or lower individual-level income or occupational class), noting possible differential misclassification across indicators. They offered several possible explanations, including healthcare access, baseline health status, occupational exposures, and nutrition, and noted that SEP may not be independent of age, race, and sex, the other three modifiers considered. To more clearly identify those aspects of SEP driving susceptibility, each of the studies represented in these reviews would require detailed data on those possible explanatory variables, including psychosocial stress, which does not yet exist in most large administrative datasets.

Outside these reviews, we found two additional studies of interaction effects on mortality - one time series and one casecrossover - reporting mixed results for SEP-related susceptibility to acute air pollution exposures (Table 1). The APHENA (Air Pollution and Health: a European and North American
Approach) studies included data from 15 US cities, finding higher $\mathrm{PM}_{10}(\mathrm{PM}$ with an aerodynamic diameter of $\leq 10 \mu \mathrm{m})$ risk estimates in locations with higher local unemployment rates (the only SEP indicator available across all cities) [31]. In contrast, a case-crossover study of ozone $\left(\mathrm{O}_{3}\right)$ on mortality in eastern Massachusetts examined almost 160,000 non-accidental deaths, finding no effect modification by individual SEP [32].

We found only one study of SEP modification of air pollution effects on cardiovascular outcomes, a cross-sectional analysis reporting weak modification in the counter-hypothesized direction, with the strongest associations between $\mathrm{PM}_{2.5}$ (PM with an aerodynamic diameter of $\leq 2.5 \mu \mathrm{m}$ ) and blood pressure among participants in the highest-SEP decile in the Multi-Ethnic Study of Atherosclerosis (MESA) [34•].

For respiratory disease, we identified two studies. A timeseries study of $\mathrm{PM}_{2.5}$ and childhood respiratory hospitalizations in Southern California reported stronger effects in lowerSEP zip codes, as measured by the composite Townsend Index [35]. The authors hypothesized that effects may be due to spatial variation in the chemical composition of fine particles, or to unmeasured exposures associated with crowding, unemployment, or commuting patterns. A prospective cohort study, also of Southern California children, observed stronger effects of traffic-related air pollution and in utero tobacco smoke on asthma etiology among children of lower-SEP (education) parents [40]. In addition, a health impact assessment in New York City (NYC) estimated rates of $\mathrm{PM}_{2.5}$-attributable asthma emergency department visits that were 4.5 times higher in lower-SEP (higher-poverty) neighborhoods [36॰].

We found only one study testing interactive effects on birth outcomes; in North Carolina, Gray et al. found independent effects of maternal and census-tract SEP (household income), $\mathrm{PM}_{2.5}$, and $\mathrm{O}_{3}$ on term birth weight and preterm birth, but no significant interaction [37].

We identified one epidemiological study of SEP modification of $\mathrm{Pb}$ effects on health. In a cross-sectional analysis of National Health and Nutrition Examination Survey (NHANES) data; Hicken et al. found that blood $\mathrm{Pb}$ was positively associated with blood pressure (BP) only among black (vs. white) adults, with stronger associations among lower-income black participants [38]. The current search did not identify any studies on $\mathrm{Pb}$ and SEP interplay with childhood neurodevelopment, or with cardiovascular disease in adults; however, other studies may well have examined these effects without reporting these in the main findings, and hence were not identifiable in our search.

In sum, of the six studies reporting empirical data on air pollution effects, only three (two time series and one prospective cohort) suggest greater susceptibility with lower SEP, although these studies varied greatly in populations (adults and children) and SEP metrics (education, income, and composite index), limiting comparability. Further methodological challenges in making comparisons across studies include 
Table 1 Epidemiologic studies examining modification of pollution health effects by socioeconomic position

\begin{tabular}{|c|c|c|c|c|c|c|}
\hline $\begin{array}{l}\text { First author, } \\
\text { year }\end{array}$ & Design & Population & Exposure(s) & SEP measure(s) & Outcome(s) & Results \\
\hline \multicolumn{7}{|c|}{ Air pollution studies } \\
\hline $\begin{array}{r}\text { Katsouyanni } \\
\text { [31], } 2009\end{array}$ & $\begin{array}{l}\text { Multi-city time } \\
\text { series }\end{array}$ & $\begin{array}{l}\text { Adult residents of } 15 \\
\text { US and } 22 \text { European } \\
\text { cities }\end{array}$ & $\begin{array}{l}\text { Daily } \mathrm{PM}_{10} \\
\text { Daily } \mathrm{O}_{3}\end{array}$ & Unemployment rate & $\begin{array}{l}\text { Mortality } \\
\text { Hospitalizations }\end{array}$ & $\begin{array}{l}\text { Stronger } \mathrm{PM}_{10} \text { effect } \\
\text { estimates with } \\
\text { higher } \\
\text { unemployment } \\
\text { rates }\end{array}$ \\
\hline Ren [32], 2010 & Case-crossover & $\begin{array}{l}\text { 157,197 non-accidental } \\
\text { deaths among } \\
\text { Massachusetts } \\
\text { adults over age } \\
35 \text { years, } 1995- \\
2002\end{array}$ & $8-\mathrm{h} \mathrm{O}_{3}$ & $\begin{array}{l}\text { Individual SEP (race, } \\
\text { gender, education, } \\
\text { marital status, } \\
\text { household income) } \\
\text { Census block group } \\
\text { median income and } \\
\text { percent poverty }\end{array}$ & Mortality & $\begin{array}{l}\text { No significant effect } \\
\text { modification by } \\
\text { individual or } \\
\text { census block SEP }\end{array}$ \\
\hline $\begin{array}{l}\text { Hicken [34], } \\
2013\end{array}$ & Cross-sectional & $\begin{array}{l}\text { 6,814 US adults aged } \\
45-84 \text { years in } 6 \\
\text { metropolitan areas }\end{array}$ & $\begin{array}{l}\text { Prior-month mean } \\
\mathrm{PM}_{2.5} \text { from } \\
\text { regulatory } \\
\text { monitors }\end{array}$ & $\begin{array}{l}\text { Individual } \\
\text { race/ethnicity, } \\
\text { education, family } \\
\text { income } \\
\text { Census tract median } \\
\text { household income }\end{array}$ & Blood pressure & $\begin{array}{l}\text { Weak evidence of } \\
\text { stronger } \mathrm{PM}_{2.5} \\
\text { effects among } \\
\text { individuals of } \\
\text { higher } \text { SEP } \\
\text { (education, } \\
\text { income, and } \\
\text { census tract } \\
\text { median income) }\end{array}$ \\
\hline Yap [35], 2013 & Time series & $\begin{array}{l}\text { All children aged 1-9 } \\
\text { years in } 12 \text { Southern } \\
\text { California Counties, } \\
\text { 2000-2005 }\end{array}$ & Daily $\mathrm{PM}_{2.5}$ & $\begin{array}{l}\text { Zip code SEP by } \\
\text { Townsend Index }\end{array}$ & $\begin{array}{l}\text { Respiratory } \\
\text { hospitalizations }\end{array}$ & $\begin{array}{l}\text { Stronger (positive) } \\
\quad \text { impact of } \mathrm{PM}_{2.5} \\
\text { on hospitalizations } \\
\text { in lower-SEP } \\
\text { areas }\end{array}$ \\
\hline $\begin{array}{r}\text { Shandarkass } \\
{[40], 2009}\end{array}$ & $\begin{array}{l}\text { Prospective } \\
\text { cohort }\end{array}$ & $\begin{array}{l}\text { 2,497 Southern } \\
\text { California children } \\
\text { aged 5-9 years at } \\
\text { baseline }\end{array}$ & $\begin{array}{l}\text { TRP } \\
\text { ITS }\end{array}$ & Parental education & $\begin{array}{r}\text { Diagnosed new } \\
\text { asthma onset }\end{array}$ & $\begin{array}{l}\text { Stronger effects of } \\
\text { TRP and ITS } \\
\text { among children of } \\
\text { lower-SEP parents }\end{array}$ \\
\hline $\begin{array}{l}\text { Gray [37], } \\
2014\end{array}$ & $\begin{array}{l}\text { Spatially- } \\
\text { resolved } \\
\text { time series }\end{array}$ & $\begin{array}{l}\text { North Carolina births } \\
\text { 2002-2006 }\end{array}$ & $\begin{array}{l}\mathrm{PM}_{2.5} \\
\mathrm{O}_{3}\end{array}$ & $\begin{array}{l}\text { Maternal race, education } \\
\text { Census tract household } \\
\text { income }\end{array}$ & $\begin{array}{l}\text { Birth weight } \\
\text { Preterm birth }\end{array}$ & $\begin{array}{c}\text { No significant } \\
\text { interactions } \\
\text { identified }\end{array}$ \\
\hline \multicolumn{7}{|l|}{ Lead study } \\
\hline $\begin{array}{l}\text { Hicken [38], } \\
2012\end{array}$ & Cross-sectional & $\begin{array}{l}\text { NHANES US adults, } \\
\text { 2001-2008 }\end{array}$ & Blood lead & $\begin{array}{l}\text { Individual race, } \\
\text { education, and } \\
\text { income }\end{array}$ & Blood pressure & $\begin{array}{l}\text { Significant (positive) } \\
\text { associations } \\
\text { between blood } \\
\text { lead and blood } \\
\text { pressure only } \\
\text { among low- } \\
\text { income black } \\
\text { adults }\end{array}$ \\
\hline
\end{tabular}

ITS in utero tobacco smoke, NHANES National Health and Nutrition Examination Survey, $O_{3}$ ozone, $P M_{2.5}$ particulate matter with an aerodynamic diameter of $\leq 2.5 \mu \mathrm{m}, P M_{10}$ particulate matter with an aerodynamic diameter of $\leq 10 \mu \mathrm{m}, S E P$ socioeconomic position, $T R P$ traffic-related pollution

limited information on the relative spatial and temporal distributions in the exposures of interest and key confounders. Additional variation may derive from model structures, confounding adjustments, definition of the study area, scale of aggregation, and other methodological considerations. Nevertheless, studies to date do suggest that SEP may influence susceptibility to air pollution, and possibly to other types of chemical exposures; further efforts to better understand these interactions, and to account for them clinically, are warranted.
Epidemiologic Evidence for Effect Modification by Stress/Stressors

We identified nine recent US studies examining effect modification by psychosocial stressors-including exposure to violence and racism — or perceived stress measures. Most are epidemiological studies of urban populations, and details are summarized in Table 2. Importantly, many stressors leading to differential susceptibility may not be associated with SEP; the 
studies reviewed here aim to examine whether chronic stress (regardless of its source) increases susceptibility to chemical exposures.
We found three recent prospective cohort studies on stressrelated modification of air pollution effects on respiratory outcomes in children. Chiu et al. reported slightly (non-

Table 2 Epidemiologic studies examining modification of pollution health effects by psychological stress

\begin{tabular}{|c|c|c|c|c|c|c|}
\hline $\begin{array}{l}\text { First author, } \\
\text { year }\end{array}$ & Design & Population & Exposure(s) & Stress measure(s) & Outcome(s) & Results \\
\hline \multicolumn{7}{|c|}{ Air pollution studies } \\
\hline${ }^{\circ}$ Chiu, 2013 & $\begin{array}{l}\text { Prospective } \\
\text { birth cohort }\end{array}$ & $\begin{array}{l}708 \text { Boston-area } \\
\text { children }\end{array}$ & $\begin{array}{l}\text { Modeled residential } \\
\text { BC }\end{array}$ & $\begin{array}{l}\text { Self-reported } \\
\text { maternal pre-natal } \\
\text { community } \\
\text { violence exposure }\end{array}$ & Repeated wheeze & $\begin{array}{l}\text { Non-significant effect } \\
\text { modification was } \\
\text { observed }\end{array}$ \\
\hline $\begin{array}{l}\text { Shandarkass } \\
{[40], 2009}\end{array}$ & $\begin{array}{l}\text { Prospective } \\
\text { cohort }\end{array}$ & $\begin{array}{l}\text { 2,497 Southern } \\
\text { California children } \\
\text { aged 5-9 years at } \\
\text { baseline }\end{array}$ & $\begin{array}{l}\text { TRP } \\
\text { ITS }\end{array}$ & PSS at baseline & $\begin{array}{r}\text { Diagnosed new } \\
\text { asthma onset }\end{array}$ & $\begin{array}{l}\text { Stronger effects of TRP } \\
\text { and ITS among } \\
\text { children of higher- } \\
\text { stress parents }\end{array}$ \\
\hline $\begin{array}{l}\text { Islam [41], } \\
2011\end{array}$ & $\begin{array}{l}\text { Prospective } \\
\text { cohort }\end{array}$ & $\begin{array}{l}\text { 1,399 Southern } \\
\text { California children } \\
\text { mean age } \\
11.2 \text { years (SD } \\
0.63 \text { ) }\end{array}$ & $\begin{array}{l}\text { Modeled NOx at } \\
\text { residence and } \\
\text { school }\end{array}$ & PSS at baseline & $\mathrm{FEV}_{1}, \mathrm{FVC}$ & $\begin{array}{l}\text { Significantly stronger } \\
\text { pollution impacts with } \\
\text { higher stress, after } \\
\text { adjustment for SEP }\end{array}$ \\
\hline $\begin{array}{l}\text { Madrigano } \\
{[42], 2012}\end{array}$ & Cross-sectional & $\begin{array}{l}699 \text { Boston-area } \\
\text { elderly men }\end{array}$ & $\begin{array}{l}\text { Central site } \mathrm{PM}_{2.5} \\
\text { and } \mathrm{BC} \text {, averaged } \\
\text { for } 4 \mathrm{~h} \text { to } 4 \text { weeks } \\
\text { before clinic visit }\end{array}$ & $\begin{array}{l}\text { Trait optimism and } \\
\text { pessimism by Life } \\
\text { Orientation Test } \\
\text { Depressive and } \\
\text { anxious symptoms } \\
\text { by Brief Symptom } \\
\text { Inventory }\end{array}$ & $\begin{array}{l}\text { DNA methylation of } \\
i N O S \text { and } G C R \\
\text { gene }\end{array}$ & $\begin{array}{l}\text { 3-4 times larger } \\
\text { reductions for } \\
\text { individuals with low } \\
\text { optimism or high } \\
\text { anxiety }\end{array}$ \\
\hline $\begin{array}{l}\text { Hicken [38], } \\
2013\end{array}$ & Cross-sectional & $\begin{array}{l}\text { 6,814 US adults aged } \\
45-84 \text { years in } 6 \\
\text { metropolitan areas }\end{array}$ & $\begin{array}{l}\text { Prior-month mean } \\
\mathrm{PM}_{2.5} \text { from } \\
\text { regulatory } \\
\text { monitors }\end{array}$ & $\begin{array}{l}\text { Self-reported chronic } \\
\text { stress, depressive } \\
\text { symptoms, trait } \\
\text { anger and anxiety, } \\
\text { lack of emotional } \\
\text { support }\end{array}$ & Blood pressure & $\begin{array}{l}\text { No significant effect } \\
\text { modification found }\end{array}$ \\
\hline \multicolumn{7}{|l|}{$\mathrm{Pb}$ studies } \\
\hline $\begin{array}{l}\text { Zota [23] } \\
\quad 2013\end{array}$ & Cross-sectional & $\begin{array}{l}\text { 8,194 US adults in } \\
\text { NHANES, 1999- } \\
2008\end{array}$ & Blood $\mathrm{Pb}$ & $\begin{array}{l}\text { Allostatic load, as } \\
\text { sum of } 7 \text { measures } \\
\text { of cardiovascular, } \\
\text { inflammatory, } \\
\text { endocrine } \\
\text { dysregulation }\end{array}$ & Blood pressure & $\begin{array}{l}\text { Suggestion of stronger } \\
\text { dose-response } \\
\text { associations between } \\
\mathrm{Pb} \text { and } \mathrm{BP} \text { (systolic } \\
\text { and diastolic) among } \\
\text { higher allostatic load } \\
\text { individuals }\end{array}$ \\
\hline $\begin{array}{l}\text { Hicken [44], } \\
2013\end{array}$ & Cross-sectional & $\begin{array}{l}\text { NHANES US adults, } \\
2005-2008\end{array}$ & Blood $\mathrm{Pb}$ & $\begin{array}{l}\text { Race } \\
\text { Depressive } \\
\text { symptoms by } \\
\text { Patient Health } \\
\text { Questionnaire } \\
\text { (PHQ-9) }\end{array}$ & Blood pressure & $\begin{array}{l}\text { Significant (positive) Pb- } \\
\text { BP association only } \\
\text { among black (vs. } \\
\text { white) adults with } \\
\text { depressive symptoms }\end{array}$ \\
\hline $\begin{array}{l}\text { Glass [43] } \\
2009\end{array}$ & $\begin{array}{l}\text { Longitudinal } \\
\text { cohort }\end{array}$ & $\begin{array}{l}\text { 1,001 Baltimore } \\
\text { adults aged } 50-70 \\
\text { years }\end{array}$ & Bone (tibia) $\mathrm{Pb}$ & $\begin{array}{l}\text { Self-identified } \\
\text { neighborhood } \\
\text { psychosocial } \\
\text { stressors }\end{array}$ & $\begin{array}{l}7 \text { measures of } \\
\text { cognitive function }\end{array}$ & $\begin{array}{l}\text { Neighborhood hazards } \\
\text { exacerbated effects of } \\
\mathrm{Pb} \text { in } 3 \text { measures } \\
\text { (language, processing } \\
\text { speed, executive } \\
\text { function) }\end{array}$ \\
\hline
\end{tabular}

$B C$ black carbon, $B P$ blood pressure, $F E V_{1}$ forced expiratory volume in $1 \mathrm{~s}, F V C$ forced vital capacity, GCR glucocorticoid receptor, $i N O S$ inducible nitric oxide synthase, ITS in utero tobacco smoke,

NHANES National Health and Nutrition Examination Survey, $N O x$ nitrogen oxides, $O_{3}$ ozone, $P b$ lead, $P M_{2.5}$ particulate matter with an aerodynamic diameter of $\leq 2.5 \mu \mathrm{m}, P S S$ parental perceived stress scale, $S D$ standard deviation, $S E P$ socioeconomic position, TRP traffic-related pollution 
significantly) stronger associations between black carbon (BC) and childhood wheeze among children of mothers reporting higher pre-natal exposures to community violence [39]. In a prospective cohort, Shankardass et al. reported stronger effects of traffic-related pollution and in utero tobacco smoke on asthma onset among children of parents reporting higher perceived stress [40]. Islam et al. found greater impacts of residential and school nitrogen oxides concentrations on forced expiratory volume in $1 \mathrm{~s}$ and forced vital capacity among children of parents reporting higher perceived stress, after adjusting for household SEP [41].

We found one cross-sectional study of cardiovascular outcomes; Hicken et al. explored self-reported chronic stress, depression, and anxiety as potential effect modifiers of associations between $\mathrm{PM}_{2.5}$ effects on blood pressure among adults in six US cities, but found no significant effect modification [34•].

Finally, one cross-sectional study considered interaction effects on epigenetic processes; Madrigano et al. reported that $\mathrm{PM}$ and $\mathrm{BC}$ exposures were associated with DNA methylation reductions three to four times larger among older men reporting greater stress (as measured by lower optimism or higher anxiety) in the Normative Aging Study [42].

Three recent studies explore stress-related modification of $\mathrm{Pb}$ effects on health in adult populations. A cross-sectional analysis of NHANES data by Zota et al. reported that higher allostatic load (used as a proxy measure of stress, and assessed using a 7-item composite of indicators of cardiometabolic dysregulation) heightened associations between blood $\mathrm{Pb}$ and blood pressure [23]. In a longitudinal cohort of older adults in Baltimore, Maryland, Glass et al. found heightened effects of bone $\mathrm{Pb}$ on cognitive function with greater exposures to self-identified neighborhood psychosocial stressors [43]. Finally, Hicken et al. found that, among NHANES participants with depressive symptoms, there were stronger associations between blood $\mathrm{Pb}$ and blood pressure among black than white participants [44].

In sum, most identified studies (seven of nine) observe increased susceptibility with chronic stress, measured in various ways. Altered susceptibility was evident in both adult and child populations, across a range of outcomes (respiratory and cardiovascular outcomes, cognitive function, and DNA methylation), and study designs. Further, it is notable that findings were generally maintained even in studies that also accounted for SEP. Such findings do suggest that the interplay between chronic stress and chemical exposures may be an important combination of exposures to consider for effective intervention and prevention strategies.

\section{Toxicologic Evidence for Effect Modification} by Stress/Stressors

There is a small literature on animal studies of stress-related susceptibility to air pollution mixtures; the two studies we identified reported significant effects in the hypothesized direction (Table 3). Clougherty et al. found an elevated impact of concentrated ambient $\mathrm{PM}_{2.5}$ on respiratory function in rats exposed to a strong chronic stressor (social dominance paradigm) [45•]. Bolton et al. also observed stronger effects of diesel exhaust particles on anxiety symptoms among mouse pups exposed to maternal restraint stress; among male pups in that study, combined exposures also increased inflammatory cytokines in the brain [e.g., higher interleukin (IL)-1 $\beta$, lower IL-10] [46].

A somewhat richer and more nuanced toxicologic literature has examined chronic stress as a modifier of $\mathrm{Pb}$ impacts on the brain and behavior. Rossi-George et al. reported poorer response times among rats exposed to both $\mathrm{Pb}$ and restraint stress, and results were comparable with stress induced either pre-natally (maternal) or post-natally [47]. Cory-Slechta et al. further found that positive behavioral experiences (food reward) may buffer some impacts of $\mathrm{Pb}$ and pre-natal stress on monoamines and amino acids in the offspring rat brain [49•]. Finally, counter to initial hypotheses, Cory-Slechta et al. found some cognitive enhancements among male rats exposed to pre-natal restraint stress, which were more strongly exacerbated by post-natal than maternal $\mathrm{Pb}[48]$.

\section{Evidence for Common Patterning Among SEP and Pollution}

SEP and pollution exposures are commonly confounded. Thus, in order to evaluate effectively the portion of SEP effects that may be due to stress - and then to quantify stress-related pollution susceptibility - an important first step is disentangling effects of exposure to SEP from the effects of pollution. Eight recent studies have examined co-patterning, and, as expected, given the vast literature on environmental justice, most found that pollution and low SEP follow similar spatial patterning. For example, in a nationwide study, Clark et al. reported higher modeled nitrogen dioxide $\left(\mathrm{NO}_{2}\right)$ exposures for the majority of non-white, higher poverty, and lower average education communities, except American Indian communities [50]. In the same study, non-whites had higher $\mathrm{NO}_{2}$ exposures, even after income adjustment. Brochu et al. also found significantly higher model-based $\mathrm{PM}_{2.5}$ and $\mathrm{PM}_{10}$ in lower-SEP census tracts across the Northeastern USA [51].

Hajat et al. found inverse associations with air pollution for both individual and census-tract SEP among MESA participants in all but two cities: NYC and Chicago, Illinois [52]. Gray et al. found higher spatial estimates of $\mathrm{PM}_{2.5}$ in lowerSEP and higher-minority census tracts in North Carolina, with opposite results for the secondary pollutant $\mathrm{O}_{3}$ [53]. A spatial analysis in Charleston, South Carolina, found higher densities of toxic release inventory (TRI) facilities in census tracts with higher percentages of non-white or poor residents [54]. Su et al. found higher $\mathrm{NO}_{2}$ and $\mathrm{PM}_{2.5}$ in the parks of lower-SEP 
Table 3 Toxicologic studies examining modification of pollution health effects by psychological stress

\begin{tabular}{|c|c|c|c|c|c|}
\hline First author, year & Species & Exposure(s) & Stress exposure(s) & Outcome(s) & Results \\
\hline \multicolumn{6}{|l|}{ Air pollution studies } \\
\hline Clougherty [45•], 2010 & Rats & CAPs & Social dominance paradigm & Respiratory function & $\begin{array}{l}\text { Stronger impact of CAPs } \\
\text { (increased respiratory rate, } \\
\text { lower flows and volumes) with } \\
\text { stress }\end{array}$ \\
\hline Bolton [46], 2013 & Mice & DEPs & Maternal restraint stress & $\begin{array}{l}\text { Anxiety symptoms, } \\
\text { inflammatory cytokines in } \\
\text { the brain }\end{array}$ & $\begin{array}{l}\text { Stronger impacts of DEPs on } \\
\text { anxiety symptoms with late- } \\
\text { gestation stress exposures } \\
\text { For male pups, greater impact of } \\
\text { DEPs on cytokines with stress } \\
\text { exposures }\end{array}$ \\
\hline \multicolumn{6}{|l|}{$\mathrm{Pb}$ studies } \\
\hline Rossi-George [47], 2011 & Rats & $\mathrm{Pb}$ & $\begin{array}{l}\text { Pre-natal (maternal) or post- } \\
\text { natal restraint stress }\end{array}$ & Response times & $\begin{array}{l}\text { Poorer response times for rats } \\
\text { with both exposures }(\mathrm{Pb} \text { and } \\
\text { stress in either period) }\end{array}$ \\
\hline Cory-Slechta [48], 2012 & Rats & $\mathrm{Pb}$ & $\begin{array}{l}\text { Pre-natal (maternal) or post- } \\
\text { natal restraint stress }\end{array}$ & Cognitive function & $\begin{array}{l}\text { Some cognitive enhancements in } \\
\text { male rats with pre-natal stress, } \\
\text { exacerbated more by post-natal } \\
\text { (vs. maternal) } \mathrm{Pb}\end{array}$ \\
\hline Cory-Slechta [49•], 2013 & Rats & $\mathrm{Pb}$ & $\begin{array}{l}\text { Forced swim (negative), } \\
\text { Food reward (positive) }\end{array}$ & $\begin{array}{l}\text { Monoamines and amino acids } \\
\text { in brain of offspring }\end{array}$ & $\begin{array}{l}\text { Negative experiences } \\
\text { exacerbated, and positive } \\
\text { experiences mitigated, the } \\
\text { effects of } \mathrm{Pb}\end{array}$ \\
\hline
\end{tabular}

$C A P s$ concentrated ambient particles, $D E P S$ diesel exhaust particles, $P b$ lead

and higher-minority neighborhoods of Los Angeles, California, than in other parks [55].

Fewer studies have documented differential indoor exposures. Storm et al. found strong SEP disparities in perchloroethelyne (PERC) exposures near dry cleaning operations in NYC; PERC exposures were five times higher in minority than in non-minority homes in their dataset, and six times higher in lower- than in higher-income homes [56]. Adamkiewicz et al. reported higher indoor concentrations of $\mathrm{NO}_{2}$ and $\mathrm{PM}_{2.5}$ in lower-SEP households in Boston, Massachusetts [57].

With some exceptions, studies generally document higher chemical exposures in lower-income communities. This cooccurrence of socioeconomic disadvantage and pollutant exposures points to the risk for confounding in epidemiological studies, and the potential for synergistic effects. As such, further development of refined methods for quantifying socioeconomic variation in exposures, and for accurately accounting for differential impacts of exposure in epidemiologic investigations, are needed.

Evidence for Common Patterning Among Chronic Stress/Stressors and Pollution

Social stressors and pollutant exposures are often correlated in space and time, leading to potential confounding in epidemiology. For example, traffic-related air pollution may be inherently confounded by traffic-related noise, an association examined in two recent studies. A roadside study in two cities examined decay curves in traffic-related pollution and noise, documenting elevations in both along major roadways [58]. Another study conducted a spatial analysis of noise and air pollution in NYC, and reported positive correlations between integrated noise and traffic-related pollutants $(\mathrm{BC}$, nitric oxide, $\mathrm{NO}_{2}$ ), with weaker correlations for intermittent noise or pollutants less correlated with traffic $\left(\mathrm{PM}_{2.5}\right)$ [59]. Notably, we identified no published studies to date on correlations between pollution and individual-level perceived stress measures. To this end, there is a need to document spatial patterning between multiple pollutants and measures of individuallevel perceived stress, in a range of settings.

Future Directions and Outstanding Issues

\section{Relative Temporality Between Stressors and Pollution Exposures}

In our prior review, we underscored the importance of measuring psychosocial stressor and pollution exposures in a manner temporally appropriate to the hypothesized disease processes. Clearly, in most cases, a stressor needs to occur prior to, or concurrent with, a chemical exposure to plausibly modify its biologic effect. This timecourse also needs to reflect the etiologic window for the disease in question; a 
long-latency cancer, for example, is unlikely to arise from any combination of exposures in only the preceding months. This issue is further complicated as both stress and pollution are often examined as chronic exposures, accumulating over months or years, although both exposures are actually highly variable over time.

As such, stress exposure assessments need be designed to accurately capture the hypothesized window of vulnerability, or observed effect modification may be dampened or even reversed. For example, in one study of stress-pollution interactions, we required stressor events to occur prior to $\mathrm{NO}_{2}$ exposures, then tested seven different exposure windows, finding the strongest effects for $\mathrm{NO}_{2}$ during the year of diagnosis. The analysis of these relative windows supported a conceptual model wherein chronic stress 'primed' the system towards susceptibility, and $\mathrm{NO}_{2}$ 'triggered' asthma onset [25].

\section{Pollution as a Chronic Stressor}

Perceived pollution exposure (and the concern for consequent health effects) may itself be a chronic psychological stressor, complicating relationships among and between psychological stressors and pollution exposures. For example, some recent studies have examined impacts of pollution (or perceived pollution exposures) on psychological stress. Horton et al. documented that malodor and air pollution exposures near an industrial hog operation in eastern North Carolina predicted stress and negative mood [60]. In another study, exposures near a petrochemical plant in Texas predicted subjective exposures (concern about health risk from the plant) and biological markers of psychological stress (e.g., IL-6, viral reactivation) [61]. Couch and Coles described a number of case studies linking "chronic technological disasters" (environmental contamination) with distress in communities, with the aim of identifying best practices for risk assessment and decision making [62]. Finally, there is emerging evidence that rapidly expanding industrial operations (e.g., unconventional natural gas drilling) may produce significant distress in communities [63].

Another challenging aspect of this research is that chemical exposures may also cause physiologic alterations in stress response systems, further complicating directionality in these interactions. For example, Huijbregts et al. documented elevated stress responsivity (salivary cortisol and alpha-amylase) among children exposed to pre-natal tobacco smoke [64]. Fortin et al. found dampened cortisol response (adrenal hyporesponsiveness) among participants with higher blood $\mathrm{Pb}$ associated with occupational exposures [65]. Bolton et al. found heightened anxiety symptoms in mice exposed to both maternal stress and diesel exhaust particles [46]. Ultimately, more sophisticated models need be developed to account for these complex effects.
'Validating' Chronic Stressor Indicators

A tremendous challenge in research on the health effects of SEP is that SEP indicates a broad range of lifecourse (and prenatal) social and physical exposures. For investigators principally interested in the effects of chronic stress but, due to logistical constraints, need to use SEP variables as proxy indicators, there are several possible approaches to verifying that the selected indicator is interpretable. First, researchers can establish that the selected SEP indicators are appropriate to local patterns of socioeconomic deprivation, which has been linked with chronic stress. For example, in regions where food security or water scarcity are critical issues, indicators of such resource access may be more germane than income or education per se. Composite SEP metrics (e.g., Townsend Index) incorporate aspects of wealth and assets such as vehicle ownership; however, the meaning of these assets is not universal, so the salience of these components should be validated for the study population, or alternative components developed. Clearly, there are trade-offs between using locally specific indicators versus global indicators that enable broad comparisons across communities.

Ultimately, to understand both stress-related susceptibility and the extent to which SEP effects on susceptibility may be due to psychosocial stress, several approaches are needed. First, investigators need to state clearly when SEP indicators are hypothesized to proxy for stress-related susceptibility. Second, if investigators are specifically interested in stressrelated susceptibility, we urge greater attention to capturing the more specific 'stressor indicators' which commonly track with, or result from, SEP. We have been approaching this issue using Geographic Information Systems (GIS)-based indicators of SEP and social stressors throughout NYC. First, we aimed to establish which publicly available stressor indicators (e.g., crime, poverty rates) local residents perceive as relevant, via city-wide focus groups wherein residents identified key community stressors [66]. Second, we are using the information from focus groups to guide selection of GIS stressor indicators for further consideration, and to shape a city-wide survey to assess relationships between GIS-based stressor indicators and individual perceived stress. With this work, we aim to select, empirically, those GIS indicators that are reasonable proxies for individual-level chronic stress experience.

As noted previously, there is growing interest in stress biomarkers, though great care is needed to ensure that selected biomarkers accurately capture stress per se, rather than downstream disease risk, which may be impacted by multiple (possibly correlated) exposures. Accordingly, stress biomarkers may not be the ideal validation metric for psychological stress in some circumstances, especially as the range of plausible biological mechanisms impacted by stress, and thus potentially facilitating synergistic effects, is broad, and may 
vary by outcome. Air pollution studies, particularly in relation to respiratory illness, often cite inflammatory pathways, while studies on cardiovascular risk often cite endocrine and metabolic pathways. Synergistic effects on the brain have been hypothesized via systemic inflammation, vascular degeneration, and alterations in blood-brain barrier permeability [28].

Methods for Statistical and Spatial Analysis of Multiple Exposures

It is beyond the scope of this review to detail spatial statistical methods for social-environmental epidemiology, but we briefly note here two classes of spatial methods germane to complex patterning among exposures.

First, multi-level (ML) structures enable a better understanding of contextual exposure effects, and help to disentangle contextual and compositional effects [67]. However, although ML models account for nesting of individuals within areas - partitioning variance explained by individual- and group-level factors - they generally assume that areas are independent (unless covariance structures are specified), which is rarely the case across urban communities. Further, ML models do not necessarily capture continuous exposure variation (exposures are often represented as a single discrete value varying only between areas). In contrast, spatially informed regressions [e.g., simultaneous autoregressive (SAR) models, conditional autoregressive (CAR) models] allow researchers to specify hypothesized spatial dependence (autocorrelation), improving accuracy in models including spatially varying covariates or outcomes, and explicitly accounting for 'spill-over' effects between imperfectly delineated neighborhoods [68]. Thus, further development of statistical methods combining the strengths of both approaches would be of great utility.

Likewise, GIS-based tools and methods for the examination of multiple exposures in tandem are developing rapidly, for epidemiological and risk assessment purposes. For example, the US Environmental Protection Agency (EPA) has introduced GIS-based systems such as C-FERST (Community-Focused Exposure and Risk Screening Tool) to assist communities in the identification and assessment of multiple risks [69]. We note the need for attention to the structure and limitations of spatial data, often pre-aggregated to administrative units (e.g., census tract, police precinct), potentially corresponding poorly to lived neighborhood spaces [70]. Because of this concern, in our own work in NYC, we have developed and validated an online mapping interface allowing survey respondents to 'draw' perceived neighborhood boundaries, to establish whether the spatial units of aggregation in GIS-based data reflect meaningful neighborhood units [71]. We suspect that a broader effort to report whether publicly available data holds resonance to residents' lived experience, as assessed in communities across the country, would be valuable and could be used to inform a myriad of research questions, not just those on chemical and non-chemical exposures.

Implications for Cumulative Risk Assessment

Recent reviews and case studies have called for greater attention to, and improved methods for, the integration of nonchemical stressors into CRA [72-74]. Interest has been driven by environmental justice concerns of heightened chemical exposures among lower-SEP populations [75, 76], and the EPA authority to protect susceptible populations and improve population health [77]. Some reviews have proposed screening methods incorporating SEP indicators and environmental factors [78]. Accordingly, a range of social indicators have been proposed for CRA, and some reviews have clearly distinguished concepts and measures of inequity and inequality [79]. A subset of these reviews have specifically addressed stress-related susceptibility in CRA [80-83], or proposed methods for quantifying and disentangling stress from other components of SEP.

We suggest that elucidating the proportion of SEP-related susceptibility attributable to chronic stress is an important step that will provide greater insight into the interplay between chemical and non-chemical exposures, and their independent and synergistic effects on health. In fact, we propose that including SEP in CRAs without a clear causal hypothesis on which components of SEP are driving effects may obscure sources of susceptibility across populations. CRA is an intentionally broad structure, enabling applicability to a wide range of exposures and contexts. However, the use of non-specific SEP markers does not add clarity or accuracy; thus, we urge the identification of pathway-specific indicators appropriate to - and ideally validated within - communities of interest. For example, if a CRA posits stress as a key pathway, then indicators of violent crime - if strongly associated with perceived safety or hypervigilence - may prove a better indicator of susceptibility than SEP. If a CRA assumes that diet or healthcare access mediates SEP-related susceptibility, we similarly urge risk assessors to use the most specific indicator available - validating it wherever possible against individual level reports - and consider explicitly evaluating multicollinearity of SEP and stress-related factors, if these dilute the interpretability of more specific indicators.

\section{Conclusions}

To date, there is reasonable epidemiologic evidence that SEP increases susceptibility to environmental pollution. There is less accumulated evidence (indeed, many fewer studies) examining the role of psychosocial stress in mediating these 
effects. The relatively small toxicologic literature on chronic stress, however, supports the plausibility of psychosocial pathways as key mediators of pollution susceptibility.

SEP, however, remains a complex mix of social and environmental exposures accumulating over the lifecourse, and we suggest that epidemiology and risk assessment would benefit from efforts to more clearly identify the pathways through which SEP impacts health and susceptibility, and from attempts to quantify that portion of SEP-related susceptibility that is attributable to chronic stress. Accordingly, there is a need for continued development and application of analytic methods aimed at disentangling spatially confounded social and environmental exposures, and further refinement of toxicologic methods which enable well-controlled investigations of multiple exposures. With continued efforts to quantify the impacts of physical exposures within a social context, we may improve CRA and develop more effective environmental health policy.

Fundamental questions remain about the mechanisms through which SEP impacts upon health and susceptibility, and the extent of differential susceptibility to pollution by chronic stress remains undetermined. Ultimately, however, a richer understanding of these multiplicative effects on health opens new possibilities for interventions-including the possibility that social interventions may ameliorate environmental health impacts, and vice versa - through a more detailed conceptualization of social-physical environments.

\section{Compliance with Ethics Guidelines}

Conflict of Interest Jane E. Clougherty, Jessie L.C. Shmool, and Laura D. Kubzansky declare that they have no conflict of interest

Human and Animal Rights and Informed Consent This article does not contain any studies with human or animal subjects performed by any of the authors.

\section{References}

Papers of particular interest, published recently, have been highlighted as:

- Of importance

•. Of major importance

1. Krewski D, Jerrett M, Burnett RT, Ma R, Hughes E, Shi Y. Extended Follow-Up and Spatial Analysis of the American Cancer Society Study Linking Particulate Air Pollution and Mortality. Res Rep Health Eff Inst. 2009;140:5-114. discussion 115-36.

2. Jerrett M, Burnett R, Brook J, Kanaroglou P, Giovis C, Finkelstein $\mathrm{N}$, et al. Do socioeconomic characteristics modify the short term association between air pollution and mortality? Evidence from a zonal time series in Hamilton. Canada J Epidemiol Commun Health. 2004;58(1):31-40.
3. Griffith M, Tajik M, Wing S. Patterns of agricultural pesticide use in relation to socioeconomic characteristics of the population in the rural US South. Int J Health Serv. 2007;37:259-77.

4. Schwartz J. Societal benefits of reducing lead exposure. Environ Res. 1994;66(1):105-24.

5. Berkman LF, Kawachi I. Social Epidemiology. New York, NY, USA: Oxford University Press; 2000.

6. Matthews KA, Gallo LC. Psychological perspectives on pathways linking socioeconomic status and physical health. Ann Rev Psychol. 2011;62:501-30.

7. Ayer LA, Hudziak JJ. Socioeconomic risk for psychopathology: The Search for Causal Mechanisms. J Am Acad Child Adolesc Psychia. 2009;48(10):982-3.

8. Scraufnagel DE, Blasi F, Kraft M, Gaga M, Finn P, Rabe K. An Official American Thoracic Society/ European Respiratory Society Policy Statement: Disparities in Respiratory Health. Am J Respir Crit Care Med. 2013;188(7):865-71.

9. Derry HM, Fagundes CP, Andridge R, Glaser R, Malarkey WB, Kiecolt-Glaser JK. Lower subjective social status exaggerates interleukin-6 responses to a laboratory stressor. Psychoneuroendocrin. 2013;38:2676-85.

10. Theall KP, Brett ZH, Shirtcliff EA, Dunn EC, Drury SS. Neighborhood disorder and telomeres: Connecting children's exposure to community level stress and cellular response. Soc Sci Med. 2013;85:50-8.

11. Clougherty JE, Kubzansky LD. A framework for examining social stress and susceptibility to air pollution in respiratory health. Environ Health Perspec. 2009;117(9):1351-8.

12. McEwen BS, Seeman T. Protective and damaging effects of mediators of stress. Elaborating and testing the concepts of allostasis and allostatic load. Ann N Y Acad Sci. 1999;896:30-47.

13. Selye $\mathrm{H}$. The general adaptation syndrome and the diseases of adaptation. J Clin Endocr. 1946;6:117-230.

14. Glaser R, Kiecolt-Glaser JK. Stress-induced immune dysfunction: implications for health. Nat Immunol. 2005;5:243-51.

15. Miller GE, Chen E, Sze E, Marin T, Arevalo JMG, Doll R, et al. A functional genomic fingerprint of chronic stress in humans: Blunted glucocorticoid and increased NF-kappaB signaling. Biol Psychiatry. 2008;64:266-72.

16. Lu XT, Yx Z, Zhang Y, Jiang F. Psychological stress, vascular inflammation, and atherogenesis: potential roles of circulating cytokines. J Cardiovasc Pharmacol. 2013;62(1):6-12.

17. McEwen BS. Protective and damaging effects of stress mediators. N Engl J Med. 1998;338:171-9.

18. Aneshensel CS. Social Stress: Theory and Research. Ann Rev Sociol. 1992;18:15-38.

19. Cohen S, Kessler RC, Gordon LU. Strategies for measuring stress in studies of psychiatric and physical disorders. In: Cohen S, Kessler RC, Gordon LU, editors. Measuring stress: A guide for health and social scientists. New York: Oxford University Press; 1995.

20. Kubzansky LD, Winning A, Kawachi I. Affective States and Health. In: Berkman L, Kawachi I, Glymour MM, editors. Social Epidemiology: New perspectives on social determinants of global population health. New York: Oxford University Press; 2014.

21. Ewbank DC. Biomarkers in social science research on health and aging: A review of theory and practice. In: Weinstein M, Vaupel JW, Wachter KW, editors. Biosocial Surveys. Washington, D.C.: National Academies Press; 2008. p. 156-71.

22. Thurston RC, Kubzansky LD. Multiple sources of psychosocial disadvantage and risk of coronary heart disease. Psychosom Med. 2007;69(8):748-55.

23. Zota AR, Shenassa ED, Morello-Frosch R. Allostatic load amplifies the effect of blood lead levels on elevated blood pressure among middle-aged U.S. adults: a cross-sectional study. Environ Health $2013 ; 12(64)$ 
24. Perera FP, Wang S, Rauh V, Zhou H, Stiger L, Camann D, et al. Prenatal Exposure to Air Pollution, Maternal Psychological Distress, and Child Behavior. Pediatrics. 2013;132:e1284-94. doi: 10.1542/peds.2012-3844.

25. Clougherty JE, Levy JI, Kubzansky LD, Ryan PB, Suglia SF, Canner MJ, et al. Synergistic effects of traffic-related air pollution and exposure to violence on urban asthma etiology. Environ Health Perspec. 2007;115(8):1140-6.

26. Cohen S, Tyrrell DAJ, Smith AP. Psychological Stress and Susceptibility to the Common Cold. N Engl J Med. 1991;325: 606-12.

27. Esparza MA, Bollati F, Garcia-Keller C, Virgolini MB, Lopez LM, Brusco A, et al. Stress-induced sensitization to cocaine: actin cytoskeleton remodeling within mesocorticolimbic nuclei. Eur J Neurosci. 2012;36(8):3103-17.

28. Sinton CM, Fitch TE, Petty F, Haley RW. Stressful manipulations that elevate corticosterone reduce blood-brain barrier permeability to pyridostigmine in the rat. Toxicol Appl Pharmacol. 2000;165: 99-105.

29. Sacks JD, Stanek LW, Luben TJ, Johns DO, Buckley BJ, Brown JS, et al. Particulate matter-induced health effects: Who is susceptible? Environ Health Perspec. 2011;119(4):446-54.

30. Bell ML, Zanobetti A, Dominici F. Evidence on vulnerability and susceptibility to Health Risks associated with short-term exposure to particulate matter: A systematic review and meta-analysis. Am J Epidem. 2013;178(6):865-76. This paper reviewed the evidence to date on multiple potential modifiers of the effects of fine particulate matter on health.

31. Katsouyanni K, Samet JM, Anderson HR, Atkinson R, Le Tertre A, Medina S, et al. Air pollution and health: a European and North American approach (APHENA). Res Rep Health Eff Inst. 2009;142:5-90.

32. Ren C, Mellt S, Schwartz J. Modifiers of short-term effects of ozone on mortality in eastern Massachusetts - A case-crossover analysis at individual level. Environ Health. 2010;9:3.

33. Dragano N, Hoffman B, Moebus S, Mohlenkamp S, Stang A, Verde $\mathrm{PE}$, et al. Traffic exposure and subclinical cardiovascular disease: is the association modified by socioeconomic characteristics of individuals and neighbourhoods? Results from a multilevel study in an urban region. Occup Environ Med. 2009;66:628-35.

34. Hicken MT, Adar SD, Diez-Roux AV, O’Neill MS, Magzamen S, Auchincloss AH, et al. Do Psychosocial Stress and Social Disadvantage Modify the Association Between Air Pollution and Blood Pressure? Am J Epidemiol. 2013;178(10):1550-62. This paper identified stronger associations between air pollution and blood pressure in higher-SEP communities in two large cities potentially indicating higher exposures in some affluent urban communities, or pointing to non-linearities in the SEP-pollution interaction.

35. Yap P-S, Gilbreath S, Garcia C, Jareen N, Goodrich B. The Influence of Socioeconomic Markers on the Association Between Fine Particulate Matter and Hospital Admissions for Respiratory Conditions Among Children. Am J Public Health. 2013;103(4): 695-702.

36. Kheirbek I, Wheeler K, Walters S, Kass D, Matte T. PM ${ }_{25}$ and ozone health impacts and disparities in New York City: sensitivity to spatial and temporal resolution. Air Qual Atmos Health. 2013;6(2):473-86. This paper indicated higher PM- and ozoneattributable health effects in lower-SEP communities, even where some higher-SEP communities may have higher pollution exposures.

37. Gray SC, Edwards SE, Schultz BD, Miranda ML. Assessing the impact of race, social factors and air pollution on birth outcomes: a population-based study. Environ Health. 2014;13:4.

38. Hicken MT, Gee GC, Morenoff J, Connell CM, Snow RC, Hu H. A novel look at racial health disparities: The interaction between social disadvantage and environmental health. Am J Public Health. 2012;102(12):2344-51.

39. Chiu Y-H M, Coull BA, Sternthal MJ, Kloog I, Schwartz, Cohen S, et al. Effects of prenatal community violence and ambient air pollution on childhood wheeze in an urban population. J Allergy Clin Immunol. 2014;133(3):713-22.

40. Shankardass K, McConnell R, Jerrett M, Milam J, Richardson J, Berhane K. Parental stress increases the likelihood of traffic-related air pollution on childhood asthma incidence. Proc Natl Acad Sci U S A. 2009;106(30):12406-11.

41. Islam T, Urman R, Gauderman WJ, Milam J, Lurmann F, Shankardass K, et al. Parental stress increases the detrimental effect of traffic exposure on children's lung function. Am J Respir Crit Care Med. 2011;184(7):822-7.

42. Madrigano J, Baccarelli A, Mittleman MA, Sparrow D, Spiro A, Vokonas PS, et al. Air pollution and DNA methylation: interaction by psychological factors in the VA Normative Aging Study. Am J Epidemiol. 2012;176(3):224-32.

43. Glass TA, Bandeen-Roche K, McAtee M, Bolla K, Todd AC, Schwartz BS. Neighborhood psychosocial hazards and the association of cumulative lead dose with cognitive function in older adults. Am J Epidemiol. 2009;169(6):683-92.

44. Hicken MT, Gee GC, Connell C, Snow RC, Morenoff J, Hu H. Black-white blood pressure disparities: depressive symptoms and differential vulnerability to blood lead. Environ Health Perspect. 2013;121(2):205-9.

45. Clougherty JE, Rossi CA, Lawrence J, Long MS, Diaz EA, Lim RH, et al. Chronic social stress and susceptibility to concentrated ambient fine particles in rats. Environ Health Perspect. 2010;118(6):769-75. This paper documented, in a controlled experiment, a heightened respiratory response to fine particle exposures among animals undergoing a stress paradigm, akin to prior epidemiological results.

46. Bolton JL, Huff NC, Smith SH, Mason SN, Foster WM, Auten RL. Maternal stress and effects of prenatal air pollution on offspring mental health outcomes in mice. Environ Health Perspect. 2013;121:1075-82.

47. Rossi-George A, Virgolini MB, Weston D, Thiruchelvam M, CorySlechta DA. Interactions of lifetime lead exposure and stress: Behavioral, neurochemical and HPA axis effects. Neurotox. 2011;32(1):83-99.

48. Cory-Slechta DA, Virgolini MB, Liu S, Weston D. Enhanced stimulus sequent-dependent repeated learning in male offspring after prenatal stress alone or in conjunction with lead exposure. Neurotox. 2012;33(5):1188-202.

49. Cory-Slechta DA, Merchant-Borna K, Allen JL, Liu S, Weston D, Conrad K. Variations in the nature of behavioral experience can differentially alter the consequences of developmental exposures to lead, prenatal stress, and the combination. Toxicol Sci. 2013;131(1): 194-205. This paper demonstrated the potential for enrichment experiences to ameliorate some of the impact of stress exposures on susceptibility to lead.

50. Clark L, Millet DB, Bechle MJ, Marshall JD. Environmental injustice and inequality: $\mathrm{NO}_{2}$ air pollution in the United States. Conference Proceeding: International Society for Environmental Epidemiology (ISEE); 19-23 Aug 2013; Basel

51. Brochu PJ, Yanosky JD, Paciorek CJ, Schwartz J, Chen JT, Herrick $\mathrm{RF}$, et al. Particulate air pollution and socioeconomic position in rural and urban areas of the northeastern United States. Am J Public Health. 2011;101(51):S224-30.

52. Hajat A, Diez-Roux AV, Adar SD, Auchincloss AH, Lovasi GS, O’Neill MS, et al. Air pollution and individual and neighborhood socioeconomic status: Evidence from the Multi-Ethnic Study of Atherosclerosis (MESA). Environ Health Perspect. 2013;121(11-12):1325-33.

53. Gray SC, Edwards SE, Mirando ML. Race, socioeconomic status, and air pollution exposure in North Carolina. Environ Res. 2013;126:152-8. 
54. Wilson SM, Fraser-Rahim H, Williams E, Zhang H, Rice L, Svendsen E, et al. Assessment of the distribution of toxic release inventory facilities in metropolitan Charleston: An environmental justice case study. Am J Public Health. 2012;102(10): 1974-80.

55. Su JG, Jerrett M, de Nazelle A, Wolch J. Does exposure to air pollution in urban parks have socioeconomic, racial or ethnic gradients? Environ Res. 2011;111:319-28.

56. Storm JE, Mazor KA, Shost SJ, Serle J, Aldous KM, Blount BC. Socioeconomic disparities in indoor air, breath, and blood perchloroethylene level among adult and child residents of buildings with or without a dry cleaner. Environ Res. 2013;122:88-97.

57. Adamkiewicz G, Zota AR, Fabien P, Chahine T, Julien R, Spengler $\mathrm{J}$, et al. Moving environmental justice indoors: Understanding structural influences on residential exposure patterns in lowincome communities. Am J Public Health. 2011;101(S1):S238-45.

58. Allen RW, Davies H, Cohen MA, Mallach G, Kaufman JD, Adar SD. The spatial relationship between traffic-generated air pollution and noise in 2 US cities. Environ Res. 2009;109(3):334-42.

59. Kheirbek I, Ito K, Neitzel R, Kim J, Johnson S, Ross Z, et al. Spatial Variation in Environmental Noise and Air Pollution in New York City. J Urban Health. 2014;91:415-31.

60. Horton RA, Wing S, Marshall SW, Brownley KA. Malodor as a trigger of stress and negative mood in neighbors of industrial hog operations. Am J Public Health. 2009;99(53):S610-5.

61. Peek MK, Cutchin MP, Freeman D, Stowe RP, Goodwin JS. Environmental hazards and stress: evidence from the Texas City Stress and Health Study. J Epidem Comm Health 2009;63(10)

62. Couch SR, Coles CJ. Community Stress, Psychosocial Hazards, and EPA Decision-Making in Communities Impacted by Chronic Technological Disasters. Am J Public Health. 2011;101:S140-8.

63. Ferrar KJ, Kriesky J, Christen CL, Marshall LP, Malone SL, Sharma RK, et al. Assessment and longitudinal analysis of health impacts and stressors perceived to result from unconventional shale gas development in the Marcellus Shale region. Int J Occup Environ Health. 2013;19(2):104-12.

64. Huijbregts SCJ, van Berkela SR, Swaab-Barnevelda H, van Goozena SHM. Neurobiological and behavioral stress reactivity in children prenatally exposed to tobacco. Psychoneuroendocrin. 2011;36:913-8.

65. Fortin MC, Cory-Slechta DA, Ohman-Strickland P, Nwankwo C, Yanger TS, Todd AC, et al. Increased lead biomarker levels are associated with changes in hormonal response to stress in occupationally exposed male participants. Environ Health Perspec. 2012;120(2):278-83.

66. Carr JL, Yonas MA, Dotson Newman O, Kubzansky LD, Joseph E, Parks A, Chubb LG, Calloway C, Shepard P, Clougherty JE: Exploring the relevance of publicly-available indicators of social stressors through a spatially-informed, community-based qualitative process across New York City. International Society of Environmental Epidemiology. Columbia SC; 2012.

67. Soobader M, Cubbin C, Gee GC, Rosenbaum A, Laurenson J. Levels of analysis for the study of environmental health disparities. Environ Res. 2006;102(2):172-80.

68. Chaix B, Merlo J, Chauvin P. Comparison of a spatial approach with the multilevel approach for investigating place effects on health: the example of healthcare utilization in France. J Epidemiol Community Health. 2005;59:517-26.
69. Zartarian VG, Schultz BD. The EPA's human exposure research program for assessing cumulative risk in communities. J Expo Sci Environ Epidemiol. 2010;20(4):351-8.

70. Basta LA, Richmond TS, Wiebe DJ. Neighborhoods, daily activities, and measuring health risks experienced in urban environments. Soc Sci Med. 2010;71(11):1943-50.

71. Carr JL, Johnson I, Chubb L, Keene R, Landry P, Gradeck R, et al. Developing and validating an online GIS-based instrument to elicit perceived neighborhood information for public health research: A pilot study in New York City and Pittsburgh. Conference proceedings: International Society for Environmental Epidemiology (ISEE); 26-30 Aug 2012; Columbia (SC)

72. Lewis AS, Sax SN, Wason SC, Campleman SL. Non-chemical stressors and cumulative risk assessment: an overview of current initiatives and potential air pollutant interactions. Int J Environ Res Public Health. 2011;8(6):2020-73.

73. Sexton K, Linder SH. Cumulative risk assessment for combined health effects from chemical and nonchemical stressors. Am J Public Health. 2011;101:S81-8.

74. Wason SC, Smith TJ, Perry MJ, Levy JI. Using PhysiologicallyBased Pharmacokinetic Models to Incorporate Chemical and NonChemical Stressors into Cumulative Risk Assessment: A Case Study of Pesticide Exposures. Int J Environ Res Public Health. 2012;9:1971-83.

75. Morello-Frosch R, Zuk M, Jerrett M, Shamasunder B, Kyle $\mathrm{AD}$. Understanding the cumulative impacts of inequalities in environmental health: Implications for policy. Health Aff. 2011;30(5):879-87.

76. Hicken MT, Gragg R, Hu H. How cumulative risks warrant a shift in our approach to racial health disparities: The case of lead, stress, and hypertension. Health Aff. 2011;30(10):1895-901.

77. Alves S, Tilghman J, Rosenbaum A, Payne-Sturges DC. U.S. EPA authority to use cumulative risk assessments in environmental decision-making. Int J Environ Res Pub Health. 2012;9: 1997-2019.

78. August LM, Faust JB, Cushing L, Zeise L, Alexeeff GV. Methodological considerations in screening for cumulative environmental health impacts: Lessons learned from a pilot study in California. Int J Res Pub Health. 2012;9:3069-84.

79. Harper S, Ruder E, Roman HA, Geggel A, Nweke O, PayneSturges D, et al. Using inequality measures to incorporate environmental justice into regulatory analyses. Int J Environ Res Pub Health. 2013;10:4039-59.

80. Block ML, Elder A, Auten RL, Bilbo SD, Chen H, Chen JC. The outdoor air pollution and brain health workshop. Neurotoxicology. 2012;33(5):972-84.

81. Levy JI, Clougherty JE, deFur P. Integrating chemical and nonchemical stressors in cumulative risk assessment. U.S. EPA Risk Assessment Forum October 2011. https://d10k7k7mywg42z. cloudfront.net/assets/5231f1a1c0d7cd2e7d000005/Final_CRA Stressors_White_Paper_10_28_11.pdf. Accessed 11 Sep 2014

82. McEwen B, Tucker P. Critical biological pathways for chronic psychosocial stress and research opportunities to advance the consideration of stress in chemical risk assessment. Am J Public Health. 2011;101(51):S131-9.

83. Schwartz J, Bellinger D, Glass T. Exploring potential sources of differential vulnerability and susceptibility in risk from environmental hazards to expand the scope of risk assessment. Am J Public Health. 2011;101:S94-S101. 